\title{
The International Turn in Intellectual History
}

\section{Citation}

Armitage, David. 2014. "The International Turn in Intellectual History." In Rethinking Modern European Intellectual History eds. Darrin M McMahon and Samuel Moyn: 232-252. New York: Oxford Univ. Press.

\section{Published Version}

https://global.oup.com/academic/product/rethinking-modern-european-intellectualhistory-9780199769247?cc=us\&lang=en\&\#

\section{Permanent link}

http://nrs.harvard.edu/urn-3:HUL.InstRepos:29425097

\section{Terms of Use}

This article was downloaded from Harvard University's DASH repository, and is made available under the terms and conditions applicable to Open Access Policy Articles, as set forth at http:// nrs.harvard.edu/urn-3:HUL.InstRepos:dash.current.terms-of-use\#OAP

\section{Share Your Story}

The Harvard community has made this article openly available.

Please share how this access benefits you. Submit a story.

\section{Accessibility}




\title{
The International Turn in Intellectual History ${ }^{\dagger}$
}

\author{
DAVID ARMITAGE \\ Department of History, Harvard University
}

... ideas are the most migratory things in the world. ${ }^{1}$

On croit souvent que la vie intellectuelle est spontanément internationale.

Rien n'est plus faux. ${ }^{2}$

For most of the life-span of the historical profession, in most parts of the world, historians were committed to methodological nationalism. Like most other social scientists, they assumed that self-identifying nations, organized politically into states, were the primary objects of historical study. ${ }^{3}$ Their main tasks were accordingly to narrate how nation-states emerged, how they developed, and how they interacted with one another. Even those historians whose work deliberately crossed the borders of national histories worked along similar lines. For example, diplomatic historians used national archives to reconstruct relations among states. Historians of immigration tracked the arrival and assimilation of new peoples into existing states. ${ }^{4}$ And imperial historians studied empires as the extensions of national histories, even though they generally

\footnotetext{
${ }^{\dagger}$ Forthcoming in Darrin M. McMahon and Samuel Moyn, eds., Rethinking Modern European Intellectual History (New York: Oxford University Press, 2013). For their comments on earlier versions of this chapter, I am especially grateful to Alexander Bevilacqua, Philip Fileri, and Mira Siegelberg, to participants in a Radcliffe Exploratory Seminar at Harvard University, and to audiences in Helsinki, London, and Princeton.

${ }^{1}$ Arthur O. Lovejoy, 'Reflections on the History of Ideas,' Journal of the History of Ideas 1 (1940): 4.

2 Pierre Bourdieu, 'Les conditions sociales de la circulation internationale des idées,' Romanistische Zeitschrift für Literaturgeschichte/Cahiers d'Histoire des Littératures Romanes 14 (1990): 2.

3 '... a nation is a community of sentiment which would adequately manifest itself in a state of its own; hence, a nation is a community which normally tends to produce a state of its own': Max Weber, From Max Weber: Essays in Sociology, ed. H. H. Gerth and C. Wright Mills, new edn. (London: Routledge, 1991), 176.

${ }^{4}$ Andreas Wimmer and Nina Glick Schiller, 'Methodological Nationalism, the Social Sciences, and the Study of Migration: An Essay in Historical Epistemology,' International Migration Review 37 (2003): 576-610.
} 
maintained a strict separation between the histories of metropolitan states (mostly in Europe) and their colonies (mostly outside Europe). In all these fields, the matter of history concerned stability not mobility, what was fixed but not what was mixed.

Historians in all fields have more recently been moving towards studies they describe variously as international, transnational, comparative, and global. Their efforts have not been identical in scope, in subject matter, or in motivation, nor is there any consensus on how these non-national approaches to history should be distinguished from each other. International historians often take for granted the existence of a society of states but look beyond state boundaries to map inter-state relationships, from diplomacy and finance to migration and cultural exchanges. Transnational historians examine processes, movements, and institutions that overflow territorial boundaries: for example, the environment, organized crime, epidemics, corporations, religions, and international social movements. Comparative historians deal with distinct historical subjects-which are often, but not always, nationally defined-in conjunction with each, although not always on the basis of any actual historical connection between their objects of study. And global historians treat the history and pre-histories of globalization, the histories of objects that have become universalized, and the links between sub-global arenas such as the Atlantic, Indian, and Pacific Oceans. The family resemblance that links these approaches is the desire to go above or beyond the histories of states defined by nations and of nations bounded by states. Taken together, these projects comprise what the international turn in historical writing. ${ }^{5}$

This international turn represents perhaps the most transformative historiographical movement since the rise of social history in the 1960s and the linguistic turn of the 1970s. ${ }^{6}$ Why it has taken place simultaneously across so many areas of

\footnotetext{
${ }^{5}$ Patricia Clavin, 'Defining Transnationalism,' Contemporary European History 14 (2005): 42139; C. A. Bayly, Sven Beckert, Matthew Connelly, Isabel Hofmeyr, Wendy Kozol, and Patricia Seed, 'AHR Conversation: On Transnational History,' American Historical Review 111 (2006): 1441-64; Pierre-Yves Saunier, 'Transnational,' in Akira Iriye and Pierre-Yves Saunier, eds., The Palgrave Dictionary of Transnational History (Basingstoke: Palgrave Macmillan, 2009), 104755.

${ }^{6}$ For a broader discussion of recent 'turns' in historical writing see Judith Surkis, Gary Wilder, James W. Cook, Durba Ghosh, Julia Adeney Thomas, and Nathan Perl-Rosenthal, 'AHR Forum: Historiographic “Turns” in Critical Perspective,' American Historical Review 117 (2012): 698813.
} 
historical work would be a good question for intellectual history. However, it poses a particular problem for intellectual historians, who have so far written little about the international turn. This absence of engagement can be attributed in part to the reigning materialism of many of the strains of history that comprise the international turn in their field. Historians of capital, empire, and migration, alongside sociologists and archaeologists with global ambitions, have led debate on this movement and produced many of the major works of synthesis. For such historians, 'each age gets the thought it needs'-Buddhism; Christianity; Islam: it's all the same really. ${ }^{7}$ To them, intellectual history has seemed immaterial in both senses of that term: a kind of history from the neck up dealing with the insubstantial imaginings of disembodied beings from inner space. A major challenge for intellectual historians is how to combat this skepticism without succumbing to reductionism or dissolving the identity of their field. In this case, the best way to go forwards may be to look backwards, to the roots of intellectual history itself in the period before historiography had been adopted as a handmaiden of national states.

Intellectual history can justifiably claim to have been international history avant la lettre. As Donald Kelley has shown, the first practitioners of the history of ideas, from Thomas Stanley in mid-seventeenth-century England to Victor Cousin in postNapoleonic France, produced works that were strikingly cosmopolitan in character and content. Their histories sprang from traditions of philosophical eclecticism stretching back to Diogenes Laertius but arose most immediately from early-modern epistemological debates in which ideas were held to be independent of their origins, whether national or otherwise. ${ }^{8}$ These early forms of the history of ideas were characteristic products of a Republic of Letters that was self-consciously supranational in its affiliations and the nature of its scholarly exchanges. The Respublica literarum 'embraces the whole world and is composed of all nationalities, all social classes, all ages and both sexes,' wrote one of its citizens, the French scholar and litterateur Bonaventure d'Argonne in 1699: 'All languages, ancient as well as modern are spoken.' Within a

\footnotetext{
${ }^{7}$ Ian Morris, Why the West Rules-For Now: The Patterns of History, and What They Reveal About the Future (London: Profile Books, 2010), 420, 476, 568, 621.

${ }^{8}$ Donald R. Kelley, The Descent of Ideas: The History of Intellectual History (Aldershot: Ashgate, 2002), chs. 1-2.
} 
global community that extended from China to Peru, 'ideas were colorless, ageless, raceless, genderless ' - and, it might be added, placeless and stateless. ${ }^{9}$

Intellectual history was born international, and it remained so long after the rise of nationalism within and beyond the historical profession. The logic of territorial statehood marked intellectual history much less than other areas of historical inquiry and it became an article of faith among historians of ideas that their objects of attention escaped national boundaries. For example, the 'New History' pioneered in the late nineteenth-century United States by Frederick Jackson Turner and James Harvey Robinson questioned nationalist historiography at the moment of its birth and drew inspiration from those historical phenomena that evaded its clutches. As Turner noted in 1891, 'Ideas, commodities even, refuse the bounds of a nation. ... This is true especially of our modern world with its complex commerce and means of intellectual connection. ${ }^{10}$ Half a century later, the founding father of the modern history of ideas, Arthur O. Lovejoy, might have been recalling Turner's words when he asserted in 1938, 'Ideas are commodities which enter into interstate commerce.' How those ideas were manufactured and how they travelled, who trafficked them and who consumed them, were not questions the classic historians of ideas thought to ask: that was a task for specialists in comparative literature, 'understood to be the study of international intellectual relations'. ${ }^{11}$ Only with the rise of the social history of ideas and the history of the book would such material concerns inform the work of intellectual historians. This new strain of intellectual history also proclaimed its internationalism, as a history of livres sans frontières joined a history of ideas without borders. ${ }^{12}$ 'By their very nature, books refuse to be contained within any

\footnotetext{
${ }^{9}$ Bonaventure d'Argonne, quoted in Anthony Grafton, 'A Sketch Map of a Lost Continent: The Republic of Letters,' in Grafton, Worlds Made by Words: Scholarship and Community in the Modern West (Cambridge, Mass.: Harvard University Press, 2009), 9.

${ }^{10}$ Frederick Jackson Turner, 'The Significance of History' (1891), in Turner, The Early Writings of Frederick Jackson Turner, ed. Everett E. Edwards (Madison: The University of Wisconsin Press, 1938), 57; Peter Novick, That Noble Dream: The "Objectivity Question" and the American Historical Profession (Cambridge: Cambridge University Press, 1988), 89-95.

${ }^{11}$ Arthur O. Lovejoy, 'The Historiography of Ideas' (1938), in Lovejoy, Essays in the History of Ideas (Baltimore: The Johns Hopkins University Press, 1948), 3, 1.

${ }^{12}$ Leslie Howsam and James Raven, 'Introduction,' in Howsam and Raven, eds., Books between Europe and the Americas: Connections and Communities, 1620-1860 (Basingstoke: Palgrave Macmillan, 2011), 1.
} 
discipline,' Robert Darnton argued in 1994: 'They also refuse to respect national boundaries. $^{13}$

Intellectual history's innate resistance to nationalism may have had the paradoxical effect of making it harder for the field to take an international turn in more recent years. Because intellectual historians have not needed to reject national categories or to embrace cosmopolitan alternatives to them, they might be methodologically underprepared for such a movement. Indeed, the international turn has lately come to intellectual history by the academic equivalent of technological leapfrogging, as the field shifts from the non-national to the supra-national without ever having fully inhabited the national frameworks that traditionally structured most professional history-writing. ${ }^{14}$ This move entails facing up to some of the shortcomings of intellectual history as it has traditionally been practiced, especially its resistance to considering the spatial dimensions of context. And it demands greater insistence on the distinctive contributions intellectual history can make more generally to the broader international turn. Nonetheless, as I hope to show, intellectual historians possess some of the best available tools for tracing the emergence of categories such as the international and the global, for tracking the circulation of ideas, and for tackling some of the challenges raised by the international turn, among them the dangers of idealism, classism, and presentism, and the challenges of redefining context. Intellectual history may therefore have as much to offer the international turn as the international turn has to offer to intellectual history.

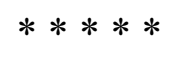

A few years ago, I suggested that 'a renaissance in the history of international thought' was beginning that might 'open up new conversations between historians, political theorists, International Relations scholars and international lawyers. ${ }^{15}$ That renaissance is now well under way and has produced the first fruits of intellectual

\footnotetext{
${ }^{13}$ Robert Darnton and Krassimira Daskalova, 'Book History, the State of Play: An Interview with Robert Darnton,' SHARP News 3, 3 (Summer 1994): 2.

${ }^{14}$ Margrit Pernau, 'Whither Conceptual History? From National to Entangled Histories,' Contributions to the History of Concepts 7 (2012): 1-11.

${ }^{15}$ David Armitage, 'The Fifty Years' Rift: Intellectual History and International Relations,' Modern Intellectual History 1 (2004): 108-09.
} 
history's international turn. This revival of the history of international thought marks the most recent of three phases of relations between intellectual history and international history: an age of engagement that lasted from roughly the end of the First World War until the 1950s; an age of estrangement running from the early 1960s to the mid-1990s; and an age of rapprochement which is still very much in progress.

In the initial age of engagement, historians of ideas were often methodologically cosmopolitan and politically internationalist in outlook, while historically-minded students of International Relations dealt openly in ideas rather than abstract models or theories. Thinkers otherwise as diverse as Hannah Arendt, Raymond Aron, Herbert Butterfield, Hans Morgenthau, Reinhold Niebuhr, Carl Schmitt, Kenneth Waltz, and Martin Wight drew upon shared historical canons even though they disagreed profoundly over such matters as the ethics of war and peace or the balance between national sovereignty and the authority of international institutions. ${ }^{16}$

During the succeeding age of estrangement, intellectual historians and international historians drew further apart. Disciplinary boundaries hardened and were more fiercely defended. The refinement of methodologies and the acceleration of professional specialization made conversations between fields less common. The separation between the domestic and the international sharpened. 'Theory'-whether political or international-lost ground to positivist models which excluded ideas and ethics from the realms of politics and International Relations, particularly in the United States. In retrospect, the May 1954 Conference on International Politics convened in New York by the Rockefeller Foundation, in which Morgenthau, Niebuhr, and others participated, now looks like the high-water mark of an ethical approach to international affairs before the triumph of behavioralist social science in the United States. ${ }^{17}$

Over the next quarter-century, intellectual historians moved ever further away from international historians as a resurgent social history pressed both fields to the

${ }^{16}$ Brunello Vigezzi, The British Committee on the Theory of International Politics (1954-1985): The Rediscovery of History (Milan: Edizioni Unicopli, 2005).

${ }^{17}$ Martin Wight, 'Why Is There No International Theory?' (1959), in Herbert Butterfield and Martin Wight, eds., Diplomatic Investigations: Essays in the Theory of International Politics (London: Allen \& Unwin, 1966), 17-34; Stanley Hoffman, 'An American Social Science: International Relations,' Daedalus 106 (1977): 41-60; Nicolas Guilhot, ed., The Invention of International Relations Theory: Realism, the Rockefeller Foundation, and the 1954 Conference on Theory (New York: Columbia University Press, 2011). 
margins of the historical profession, especially in the United States. What one clerk said to another clerk was as unfashionable as what one philosopher wrote about another philosopher. As Robert Darnton observed gloomily in a 1980 collection published on behalf of the American Historical Association, 'a malaise is spreading among intellectual historians ...... after a realignment of research during the last two decades, she now sits below the salt.' In the same volume, Charles Maier offered a similarly downbeat assessment of international history: 'The history of international relations ... [has] little sense of collective enterprise, of being at the cutting edge of historical scholarship. ${ }^{, 18}$

As so often, such intimations of obsolescence proved to be spurs to innovation. Within little more than a decade, the two fields had begun to converge again. The age of rapprochement beginning in the 1990s saw revivals in both intellectual history and international history alongside the increasing entanglement of the two fields with each other. At least some scholars of International Relations found themselves in a "postpositivist' phase marked by a renewed interest in theory, in the history of international affairs, and in the history of their own discipline. International historians became more interested in culture, ideology, and institutions, 'champions of the international turn as well as vigorous proponents of intellectual and cultural history.' At the same time, intellectual historians began to treat historically the norms and interactions between peoples, states and other corporate bodies in the world beyond the domestic sphere under the rubric of the history of international thought. ${ }^{19}$

The term 'international thought' was originally an invention of British publicists and litterateurs sympathetic to the League of Nations and nascent international institutions in the years between the two World Wars. Its original purpose had been to denote a usable past rather than to create a critical history. ${ }^{20}$ It received support from

\footnotetext{
${ }^{18}$ Robert Darnton, 'Intellectual History and Cultural History,' in Michael Kammen, ed., The Past Before Us: Contemporary Historical Writing in the United States (Ithaca, NY: Cornell University Press, 1980), 327; Charles Maier, 'Marking Time: The Historiography of International Relations,' in Kammen, ed., The Past Before Us, 355.

19 Lucian M. Ashworth, 'Interdisciplinarity and International Relations,' European Political Science 8 (2009): 16-25; Duncan Bell, 'Writing the World: Disciplinary History and Beyond,' International Affairs 85 (2009): 3-22; Thomas W. Zeiler, 'The Diplomatic History Bandwagon: A State of the Field,' Journal of American History 95 (2009): 1053 (quoted).

${ }^{20}$ John Galsworthy, International Thought (Cambridge: Heffers, 1923); F. Melian Stawell, The Growth of International Thought (London: T. Butterworth, 1929). On their immediate
} 
equally committed internationalists across the Atlantic, notably the American international lawyer James Brown Scott, who created the earliest historical canon of works of international thought from Balthazar Ayala to Richard Zouche in the series sponsored by the Carnegie Endowment for International Peace, 'Classics of International Law' (1911-50). ${ }^{21}$ The recent revival of the history of international thought has seen it emerge as a robust field in its own right, with a more expansive and less teleological canon of authors, problems and movements, and not just as a subset of the history of political thought. ${ }^{22}$ International thought now means less a body of authoritative doctrine to be deployed for present purposes than the past tense of international thinking as the activity of theoretical reflection upon international affairs.

A humanistic return to the sources of international thought revealed the distance between what thinkers like Hugo Grotius, Thomas Hobbes, and Immanuel Kant were doing - or, just as often, what they were not attempting to do-and the uses made of them within later disciplinary histories. Grotius could have had no intention of fathering international law. Hobbes was no 'Hobbesian,' at least, as far as that term had been used as a term of art by students of International Relations. And Kant was rather more than the theorist of the 'democratic peace' to which he had been reduced by teleological internationalists since the early the twentieth century. ${ }^{23}$ For the twentieth century, we now

antecedents, see Casper Sylvest, British Liberal Internationalism, 1880-1930: Making Progress? (Manchester: Manchester University Press, 2009).

${ }^{21}$ John Hepp, 'James Brown Scott and the Rise of Public International Law,' Journal of the Gilded Age and Progressive Era 7 (2008): 151-79; Benjamin Allen Coates, 'Trans-Atlantic Advocates: American International Law and U.S. Foreign Relations, 1898-1919' (unpub. Ph.D. thesis, Columbia University, 2010), 101-05.

${ }^{22}$ Edward Keene, International Political Thought: A Historical Introduction (Cambridge: Polity, 2005); Beate Jahn, ed., Classical Theory in International Relations (Cambridge: Cambridge University Press, 2006); Duncan Bell, ed., Victorian Visions of Global Order: Empire and International Relations in Nineteenth-Century Political Thought (Cambridge: Cambridge University Press, 2007); Ian Hall and Lisa Hill, eds., British International Thinkers from Hobbes to Namier (Basingstoke: Palgrave Macmillan, 2009).

${ }^{23}$ Richard Tuck, The Rights of War and Peace: Political Thought and the International Order from Grotius to Kant (Oxford: Oxford University Press, 1999); Martine Julia van Ittersum, Profit and Principle: Hugo Grotius, Natural Rights Theories and the Rise of Dutch Power in the East Indies, 1595-1615 (Leiden: Brill, 2006); Noel Malcolm, 'Hobbes's Theory of International Relations,' in Malcolm, Aspects of Hobbes (Oxford: Oxford University Press, 2002), 432-56; Sankar Muthu, Enlightenment Against Empire (Princeton, NJ: Princeton University Press, 2003); Eric S. Easley, The War over Perpetual Peace: An Exploration into the History of a Foundational International Relations Text (Basingstoke: Palgrave Macmillan, 2004). 
have historical studies of international thinkers of all stripes from Norman Angell and Hannah Arendt to Leonard Woolf and Alfred Zimmern, with an especially vigorous cottage industry devoted to the work of Carl Schmitt. ${ }^{24}$ At the same time, self-critical disciplinary historians of International Relations and international law have, for example, exposed how a 'discourse of anarchy' contingently generated in the inter-War years became a timeless truth for the later Realist school of International Relations and have shown the complicity of idealistic international lawyers with imperial enterprises from the Belgian Congo to the Bay of Pigs. ${ }^{25}$

Intellectual historians have been well placed to assist skeptical international historians in questioning some of the basic building-blocks of their discipline. For example, no date was more foundational for International Relations than 1648 and the Peace of Westphalia. The demolition of the 'myth of 1648 ' as the origins of a world of mutually recognizing, non-interfering sovereign states was a relatively straightforward process. It relied on a reading of the treaties of Munster and Westphalia, the recognition that empires, federations and other kinds of layered or divided sovereignty were more characteristic of political authority than any alleged 'Westphalian' sovereignty, and attention to the world beyond northern Europe, to see how little respect was paid to the putative sovereignty of many of the world's peoples under the regime of empire. ${ }^{26}$ The

\footnotetext{
${ }^{24}$ David Long and Peter Wilson, eds., Thinkers of the Twenty Years' Crisis: Inter-War Idealism Reassessed (Oxford: Oxford University Press, 1995); Patricia Owens, Between War and Politics: International Relations and the Thought of Hannah Arendt (Oxford: Oxford University Press, 2007); Jeanne Morefield, Covenants without Swords: Idealist Liberalism and the Spirit of Empire (Princeton: Princeton University Press, 2005); Louiza Odysseos and Fabio Petito, eds., The International Political Thought of Carl Schmitt: Terror, Liberal War and the Crisis of Global Order (London: Routledge, 2007); William Hooker, Carl Schmitt's International Thought: Order and Orientation (Cambridge: Cambridge University Press, 2009); Stephen Legg, ed., Spatiality, Sovereignty and Carl Schmitt: Geographies of the Nomos (London, 2011).

${ }^{25}$ Brian Schmidt, The Political Discourse of Anarchy: A Disciplinary History of International Relations (Albany, NY: State University of New York Press, 1998); Martti Koskenniemi, The Gentle Civilizer of Nations: The Rise and Fall of International Law, 1870-1960 (Cambridge: Cambridge University Press, 2001).

26 Andreas Osiander, 'Sovereignty, International Relations, and the Westphalian Myth,' International Organization 55 (2001): 251-87; Benno Teschke The Myth of 1648: Class, Geopolitics and the Making of Modern International Relations (London: Verso, 2003); Benjamin Straumann, 'The Peace of Westphalia as a Secular Constitution,' Constellations 15 (2008): 17388; Pärtel Piirimäe, 'The Westphalian Myth of Sovereignty and the Idea of External Sovereignty,' in Hent Kalmo and Quentin Skinner, eds., Sovereignty in Fragments: The Past, Present and Future of a Contested Concept (Cambridge: Cambridge University Press, 2010), 64-80.
} 
Westphalian myth had in turn underpinned a set of assumptions that defined modern international thought: that states, not individuals, were the primary actors in international affairs; that the spheres of the domestic and the foreign, the inside and the outside of the state, were distinct and separate; that positive law trumped natural law; that a hierarchical standard of civilization applied across the globe; and that the international realm was anarchical and hence governed by maxims of reason of state. These fundamental assumptions were neither uniform nor uncontested but they did set the terms of debate for at least a century and a half. ${ }^{27}$

The intellectual history of the international still teems with possibilities for research. For example, what were the media for international thought, and how might they be understood using the methods of history of the book ${ }^{28}$ Starting in the late seventeenth century and continuing to the present, new and persistent genres of writing and publication, among them treaty-collections, diplomatic manuals, and histories of international relations and of the law of nations, proliferated amid the clerical, scholarly and humanistic cultures that intersected so often with transnational diplomatic and military communities: further examination of such genres might help us to understand, among other questions, why Kant cast Zum ewigen Frieden (1795) in the form of a treaty. ${ }^{29}$ What were the novel philosophical personae adopted by casuistical envoys, literary-minded administrators, and intellectuals in office in the burgeoning international institutions of the eighteenth century and beyond $?^{30}$ And how was international thought itself internationalized? To take just one example, the translation and circulation in Asia of a major vector of Henry Wheaton's Elements of International Law (1836) suggests

\footnotetext{
${ }^{27}$ David Armitage, Foundations of Modern International Thought (Cambridge: Cambridge University Press, 2013).

${ }^{28}$ For a model study of the translation and circulation of economic texts along these lines, see Sophus Reinert, Translating Empire: Emulation and the Origins of Political Economy (Cambridge, Mass.: Harvard University Press, 2011).

${ }^{29}$ For suggestive work in these directions, see Randall Lesaffer, ed., Peace Treaties and International Law in European History: From the Late Middle Ages to World War One (Cambridge: Cambridge University Press, 2004); Daniel Ménager, Diplomatie et théologie à la Renaissance (Paris: Presses Universitaires de France, 2001); Ellen M. McClure, Sunspots and the Sun King: Sovereignty and Mediation in Seventeenth-century France (Urbana: University of Illinois Press, 2006); Timothy Hampton, Fictions of Embassy: Literature and Diplomacy in Early Modern Europe (Ithaca, NY: Cornell University Press, 2009).

${ }^{30}$ Ian Hunter, 'Vattel's Law of Nations: Diplomatic Casuistry for the Protestant Nation,' Grotiana 31 (2010): 108-40.
} 
that the assumptions underlying modern international thought were becoming increasingly trans-regional, if not yet fully global, by the middle of the nineteenth century. ${ }^{31}$ In this sense, the receptivity of the world to the contagion of sovereignty which almost universally affected it still demands explanation, especially by attending to the domestic determinants and conditions of its reception and domestication. ${ }^{32}$ Only then can we fully understand the energetic co-production of the national and the international around the globe in the nineteenth and twentieth centuries. ${ }^{33}$

The internationalization of the international can also be approached through the intellectual history of international institutions. Proponents of the new international history have long urged their colleagues to 'internationalize international history' by studying non-state actors in the international realm: corporations, non-governmental organizations, transnational social movements and bodies such as the World Health Organization or the United Nations. ${ }^{34}$ This call has more recently generated new opportunities for archival intellectual histories of the Institut de Droit international, the Carnegie Endowment for International Peace, the League of Nations, UNESCO, and the European Union to name only some of the most prominent. Some of this work has been internalist and celebratory, notably that generated through the United Nations Intellectual History Project, but much of it has helped to expand the range of actors, archives, and

${ }^{31}$ Lydia H. Liu, The Clash of Empires: The Invention of China in Modern World Making (Cambridge, Mass.: Harvard University Press, 2004), 108-39; Liu, ed., Tokens of Exchange: The Problem of Translation in Global Circulations (Durham, NC: Duke University Press, 1999); Carol Gluck and Anne Lowenhaupt Tsing, eds., Words in Motion: Toward a Global Lexicon (Durham, NC: Duke University, Press, 2009).

${ }^{32}$ David Armitage, The Declaration of Independence: A Global History (Cambridge, Mass.: Harvard University Press, 2007), 107-12; C. A. Bayly, 'European Political Thought and the Wider World during the Nineteenth Century,' in Gareth Stedman Jones and Gregory Claeys, eds., The Cambridge History of Nineteenth-Century Political Thought (Cambridge: Cambridge University Press, 2011), 835-63.

${ }^{33}$ C. A. Bayly and Eugenio Biagini, eds., Giuseppe Mazzini and the Globalization of Democratic Nationalism, 1830-1920 (Oxford: Oxford University Press for the British Academy, 2008); Maurizio Isabella, Risorgimento in Exile: Italian Émigrés and the Liberal International in the Post-Napoleonic Era (Oxford: Oxford University Press, 2009).

${ }^{34}$ Akira Iriye, 'Internationalizing International History,' in Thomas Bender, ed., Rethinking American History in a Global Age (Berkeley: University of California Press, 2002), 47-62; Iriye, Global Community: The Role of International Organizations in the Making of the Contemporary World (Berkeley: University of California Press, 2002). 
institutions open to examination by intellectual historians. ${ }^{35}$ One product of this expansion has been the new history of human rights, a field now in its second wave, as it has moved from its teleological phase of telling just-so stories into a more critical literature alert to context and to discontinuity. ${ }^{36}$

Other subjects of concern to intellectual historians-the history of economic thought; conceptions of war and government; public health; and the history of sciencecan all be researched in the archives of international institutions, companies, and corporations. In this regard, modern intellectual historians can learn from those early modernists who have followed historians of science in constructing intellectual histories of the English and Dutch trading companies in the seventeenth and eighteenth centuries. ${ }^{37}$ The explosion of interest among political theorists and students of ethics in the international and global dimensions of their concerns has helped to accelerate all these developments, which took place amid an ever-growing public awareness of the transnational dimensions of human affairs captured by the catch-all term 'globalization'. ${ }^{38}$ All these movements have in turn encouraged and reinforced internal tendencies within intellectual history to reconstruct arguments dealing with matters

35 Koskenniemi, The Gentle Civilizer of Nations; Roger-Pol Droit, L'Humanité toujours à construire: regard sur l'histoire intellectuelle de l'UNESCO, 1945-2005 (Paris: UNESCO, 2005); Glenda Sluga and Sunil Amrith, 'New Histories of the United Nations,' Journal of World History 19 (2008): 251-74; Emma Rothschild, 'The Archives of Universal History,' Journal of World History 19 (2008): 375-401; Mark Mazower, Governing the World: The History of an Idea (London: Allen Lane, 2012); Richard Jolly, Louis Emmerij and Thomas G. Weiss, UN Ideas that Changed the World (Bloomington: Indiana University Press, 2009), and similar works from the United Nations Intellectual History Project.

${ }^{36}$ For the first, see e.g. Elizabeth Borgwardt, A New Deal for the World: America's Vision for Human Rights (Cambridge, Mass.: Harvard University Press, 2005); Lynn Hunt, Inventing Human Rights: A History (New York: W. W. Norton, 2007); Jenny S. Martinez, The Slave Trade and the Origins of International Humanitarian Law (New York: Oxford University Press, 2012); for the second, Samuel Moyn, The Last Utopia: Human Rights in History (Cambridge, Mass.: The Belknap Press of Harvard University Press, 2010); Stefan-Ludwig Hoffmann, ed., Human Rights in the Twentieth Century (Cambridge: Cambridge University Press, 2010); Akira Iriye, Petra Goedde, and William I. Hitchcock, eds., The Human Rights Revolution: An International History (Oxford: Oxford University Press, 2011).

${ }^{37}$ Van Ittersum, Profit and Principle; Philip J. Stern, The Company-State: Corporate Sovereignty and the Early Modern Foundations of the British Empire in India (New York: Oxford University Press, 2011).

${ }^{38}$ For an excellent primer, see Duncan Bell, ed., Ethics and World Politics (Oxford: Oxford University Press, 2010). 
beyond the nation or the state that, collectively, I have called the international turn among intellectual historians.

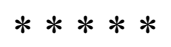

Space is the final frontier for intellectual history. The international turn has revived interest in conceptions of space by attending to arenas that were larger than nations, unconfined by the political boundaries of states, and connected by transnational linkages and circulations. Most of the world's population, for most of recorded history, lived not in nation-states but in empires, those far-flung, stratified polities that projected various kinds of universalism in order to suspend differences among populations without striving for uniformity between them. For a relatively brief period, between the early sixteenth and early twentieth centuries, some of those empires were the outgrowths of confidently national cultures, particularly in Europe and Asia, but most were pre-national or supranational in composition. Oceanic spaces connected elements of these empires in the modern period, but maritime arenas such as the Mediterranean, the Indian Ocean, the Atlantic, and the Pacific also segmented sovereignties and became cockpits of interimperial rivalry. ${ }^{39}$ In light of the long history of empire, the eternal world of states posited by modern conceptions of international relations seems fleeting, even marginal. Indeed, if by some estimates a world of true nation-states, detached from empire, emerged only with the zenith of decolonization, soon to be swept away by the wave of transnationalism that erupted after the end of the Cold War, then the heyday of the state lasted less than a generation, from about 1975 to $1989 .{ }^{40}$ All history, before and after, was either pre-national or post-national history.

By simultaneously uniting and dividing, empires spurred conceptual competition and facilitated the circulation of ideas among diasporic peoples and across commercial

${ }^{39}$ Lauren Benton, Law and Colonial Cultures: Legal Regimes in World History, 1400-1900 (Cambridge: Cambridge University Press, 2002); Benton, A Search for Sovereignty: Law and Geography in European Empires, 1400-1900 (Cambridge: Cambridge University Press, 2010).

${ }^{40}$ Frederick Cooper, Colonialism in Question: Theory, Knowledge, History (Berkeley: University of California Press, 2005); Cooper and Jane Burbank, Empires in World History: Power and the Politics of Difference (Princeton: Princeton University Press, 2010). 
routes. ${ }^{41}$ From such collisions and transmissions emerged 'competing universalisms' of empire, religion, and political economy, for instance, as well as the expansive ideologies that countered or subsumed them, such as pan-Islamism, pan-Africanism, nationalism, anti-colonialism, and other forms of 'colored cosmopolitanism'. ${ }^{42}$ Most of these movements were invisible as long as history was viewed through nation-shaped spectacles. They returned to view only when older experiences of space-more extensive, more fluid, and less confined by territorial boundaries-again framed questions about the past.

The field is rife with spatial metaphors - of ideas as 'migratory' and of books escaping the bounds of nations; of 'horizons' of understanding and the public 'sphere'; of 'localism' and 'provincialism' as determinants of ideas; and conceptions of hermeneutic 'containment' and critical 'movement,' for example - but such figures of speech do not indicate any substantive engagement so far with questions of space and place. They are instead shorthand indications that ideas lack material determinants and that they need to be placed into contexts construed almost entirely as temporal and linguistic not physical or spatial. ${ }^{43}$ 'The result is a kind of intellectual geometry-the positioning of ideas in abstract space - rather than intellectual geography'. ${ }^{44}$ Michel Foucault might have been speaking for intellectual historians specifically (rather than all historians more broadly)

\footnotetext{
${ }^{41}$ On the intellectual history of empire, see especially David Armitage, ed., Theories of Empire, 1450-1800 (Aldershot: Variorum, 1998); Ruth Ben-Ghiat, ed., Gli imperi. Dall'antichità all'età contemporanea (Bologna: Il Mulino, 2009); Sankar Muthu, ed., Empire and Modern Political Thought (Cambridge: Cambridge University Press, 2012).

42 Sugata Bose, A Hundred Horizons: The Indian Ocean in the Age of Global Empire (Cambridge, Mass.: Harvard University Press, 2006); Bose and Kris Manjapra, eds., Cosmopolitan Thought Zones: South Asia and the Global Circulation of Ideas (Basingstoke: Palgrave Macmillan, 2010); Cemil Aydin, The Politics of Anti-Westernism in Asia: Visions of World Order in Pan-Islamic and Pan-Asian Thought (New York: Columbia University Press, 2007); Erez Manela, The Wilsonian Moment: Self-Determination and the International Origins of Anticolonial Nationalism (New York: Oxford University Press, 2007); Nico Slate, Colored Cosmopolitanism: The Shared Struggle for Freedom in the United States and India (Cambridge, Mass.: Harvard University Press, 2011).

${ }^{43}$ Peter Burke, 'Context in Context,' Common Knowledge 8 (2002): 152-77; Rita Felski and Herbert F. Tucker, eds., 'Context?,' New Literary History 42 (2011), vii-xii, 557-756; Peter E. Gordon, 'Contextualism and Criticism in the History of Ideas,' in this volume.

${ }^{44}$ John Randolph, 'The Space of Intellect (and the Intellect of Space),' in this volume.
} 
when he declared in an interview: 'Space was that which was dead, fixed, non-dialectical, immobile. On the other hand, time was rich, fertile, vibrant, dialectical. ${ }^{45}$

Space can be understood intensively as well as extensively. In this regard historians of science may have much to teach both international historians and intellectual historians. A 'spatial turn' in the history of science put in doubt the universality of truth and insisted upon local knowledge: there could be no view from nowhere when every view sprang from somewhere. Ideas emerged from tightly defined spaces, from littoral beaches as well as laboratory benches, and from public drinking-houses as well as royal academies. When viewed microscopically in this way, the seamless web of abstract knowledge turned out to be a brittle mosaic of contingent concerns. ${ }^{46}$ If one aim of this literature was to debunk the presumed universality of scientific reason, another was to show just how fragments of knowledge were accumulated and collected and how their credibility was secured. 'We need to understand not only how knowledge is made in specific places but also how transactions occur between places': that is, how ideas travel, who transports them, what baggage they carry on their journeys, and how they become domesticated and naturalized upon arrival. ${ }^{47}$

This approach revealed the intricate mechanisms of information-gathering that made scientific knowledge both possible and plausible. Even the most physically isolated of thinkers, like the land-locked Isaac Newton who never saw the sea in his life, could become a global center of calculation because he commanded a worldwide web of correspondents from the Gulf of Tonkin to the Strait of Magellan. ${ }^{48}$ Corporate bodies

\footnotetext{
45 'L'espace, c'est ce qui était mort, figé, non dialectique, immobile. En revanche, le temps, c'était riche, fécond, vivant, dialectique': 'Questions à Michel Foucault sur la géographie,' Hérodote 1 (1976): 78.

${ }^{46}$ Adi Ophir and Steven Shapin, 'The Place of Knowledge: A Methodological Survey,' Science in Context 4 (1991): 3-21; Diarmid A. Finnegan, 'The Spatial Turn: Geographical Approaches to the History of Science,' Journal of the History of Biology 41 (2008): 369-88; Charles W. J. Withers, 'Place and the "Spatial Turn" in Geography and in History,' Journal of the History of Ideas 70 (2009): 637-58. More generally see Jo Guldi, 'What is the Spatial Turn?': http://spatial.scholarslab.org/spatial-turn, accessed 31 January 2012.

${ }^{47}$ Steven Shapin, 'Placing the View from Nowhere: Historical and Sociological Problems in the Location of Science,' Transactions of the Institute of British Geographers n. s. 23 (1998): 6-7 (quoted); John Tresch, 'Bringing Back the Lovejoy: History of Science and Intellectual History,' in this volume.

48 Simon Schaffer, 'Newton on the Beach: The Information Order of Principia Mathematica,' History of Science 47 (2009): 243-76.
} 
such as the Society of Jesus and the English and Dutch East India Companies facilitated big science, in the sense of the long-distance production of knowledge. ${ }^{49}$ And later 'webs of empire' dissolved distinctions between centers and peripheries as each alleged periphery earned a central place in accumulating imperial archives, testing hypotheses, and generating ideologies through inter-colonial exchanges. ${ }^{50}$ In these ways, extensively elaborated connections linked intensively cultivated locations to create new maps of knowledge and transnational canons through the transmission of ideas and information across continents and oceans.

These studies in what Pierre Bourdieu called the 'science of international relations with regard to culture' offer more generally replicable models for intellectual history. ${ }^{51}$ When conceptions of space expand, webs of significance ramify and networks of exchange proliferate to create novel contexts and unanticipated connections among them. Shifting patterns of sociability and correspondence, of the distribution of books and the spatial organization of knowledge - in rooms and buildings, streets and squares, cities and regions, countries and continents, empires and oceans - forced thinkers to reconceive the nature of their audiences, the potential impact of their arguments, and the extent of their spheres of action. In light of these considerations, to answer the question, 'What was Enlightenment?,' intellectual historians attuned to space must now ask, 'Where was Enlightenment?', a question only fully answerable in a global context across the longue durée. $^{52}$

\footnotetext{
49 Steven J. Harris, 'Long-Distance Corporations, Big Sciences, and the Geography of Knowledge,' Configurations 6 (1998): 269-304; Harold J. Cook, Matters of Exchange: Commerce, Medicine, and Science in the Dutch Golden Age (New Haven: Yale University Press, 2007); Luke Clossey, Salvation and Globalization in the Early Jesuit Missions (Cambridge: Cambridge University Press, 2008); Anna Winterbottom, 'Producing and Using the Historical Relation of Ceylon: Robert Knox, the East India Company and the Royal Society,' British Journal for the History of Science 42 (2009): 515-38.

50 Tony Ballantyne, Orientalism and Race: Aryanism in the British Empire (Basingstoke: Palgrave Macmillan, 2002), 1-17.

51 '.... une science des relations internationales en matière de culture': Bourdieu, 'Les conditions sociales de la circulation internationale des idées,' 1.

${ }^{52}$ Charles W. J. Withers, Placing the Enlightenment: Thinking Geographically about the Age of Reason (Chicago: University of Chicago Press, 2007); Susan Manning and Frank D. Cogliano, eds., The Atlantic Enlightenment (Aldershot: Ashgate, 2008); Sebastian Conrad, 'Enlightenment in Global History: A Historiographical Critique,' American Historical Review 117 (2012): 9991027.
} 
Changing conceptions of space expanded the contexts for ideas and, with them, the very possibilities for thought. The most familiar example for European intellectual historians might be the broader contexts that transoceanic exploration and colonization generated for thinkers in early modern Europe, as intercultural encounters and the proliferation of empires around the Indian Ocean, the Atlantic world and later the Pacific tested conceptions of nature, civilization, political community, property, religious diversity, and toleration, among other questions. ${ }^{53}$ For instance, John Locke, a voracious reader of travel literature, confronted instances of diversity and belief and practice drawn from accounts of five continents $;^{54}$ Thomas Hobbes, a more modest consumer of Americana, shaped his understanding of international relations by reference to ethnographic descriptions of the state of nature, ${ }^{55}$ and David Hume's political economy owed much to his Atlantic connections. ${ }^{56}$ As the 'Great Map of Mankind' was unrolled (in Edmund Burke's resonant phrase), truly global possibilities for thought opened up for the generations of thinkers writing after the mid-eighteenth century-among them Diderot, Turgot, Smith, Kant, Herder, Burke, and Bentham—with consequences for their constructions of universalism and cosmopolitanism as well as for their conceptions of culture and difference. ${ }^{57}$ Moving into the later nineteenth century, the compression of space by technology — above all, the steamship, the railway, and the telegraph — made

53 Anthony Pagden, The Fall of Natural Man: The American Indian and the Origins of Comparative Ethnology, rev. edn. (Cambridge: Cambridge University Press, 1986); Annabel Brett, Changes of State: Nature and the Limits of the City in Early Modern Natural Law (Princeton, NJ: Princeton University Press, 2011); Alan Frost, 'The Pacific Ocean: The Eighteenth Century's "New World", Studies on Voltaire and the Eighteenth Century 152 (1976): 779-822.

${ }^{54}$ Daniel Carey, Locke, Shaftesbury, and Hutcheson: Contesting Diversity in the Enlightenment and Beyond (Cambridge, 2006).

${ }^{55}$ Srinivas Aravamudan, 'Hobbes and America,' in Daniel Carey and Lynn Festa, eds., The Postcolonial Enlightenment: Eighteenth-Century Colonialism and Postcolonial Theory (Oxford, 2009), 37-70; Pat Moloney, 'Hobbes, Savagery, and International Anarchy,' American Political Science Review 105 (2011): 189-204.

${ }^{56}$ Emma Rothschild, 'The Atlantic Worlds of David Hume,' in Bernard Bailyn and Patricia L. Denault, eds., Soundings in Atlantic History: Latent Structures and Intellectual Currents, 15001830 (Cambridge, Mass.: Harvard University Press, 2009), 405-48.

${ }^{57}$ P. J. Marshall and Glyndwr Williams, The Great Map of Mankind: British Perceptions of the World in the Age of Enlightenment (London: Dent, 1982); Paul Cheney, Revolutionary Commerce: Globalization and the French Monarchy (Cambridge, MA: Harvard University Press, 2010); Muthu, Enlightenment Against Empire; Jennifer Pitts, A Turn to Empire: The Rise of Imperial Liberalism in Britain and France (Princeton, NJ: Princeton University Press, 2005); David Armitage, 'Globalizing Jeremy Bentham,' History of Political Thought 32 (2011): 63-82. 
new forms of political community imaginable over the expanses of empire and across the world. Pace Foucault, space was dynamic not static. The contexts for thinking expanded to encompass the entire globe. Modern intellectual historians accordingly have to track ideas on ever larger scales: continental, inter-regional, transoceanic, and ultimately planetary. As Heidegger, Schmitt, and Arendt were among the first to note in the midtwentieth century, outer space may be the truly final frontier for intellectual history. ${ }^{58}$

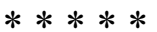

So far, my account of the international turn in intellectual history has been overwhelmingly upbeat, a tour d'horizon of achievements sustained and promises yet to be fulfilled. But every silver lining has a cloud. In what ways could the international turn possibly be a turn for the worse? This movement has not yet entered the phase of wellearned auto-critique, nor has it attracted much sustained attention from outsiders. However, some charges have already been arrayed against it, among them reification, presentism, 'classism,' and changing conceptions of context. ${ }^{59}$ None of these criticisms is peculiar to international intellectual history: all are familiar from debates on the history of ideas over at least the last half-century. Yet they have all become sharper when intellectual history extends over greater expanses of space, as new forms of disjunction between ideas and new analytical demands come to the fore.

Reification is a familiar charge, going back at least as far as the Cambridge School's criticisms of Lovejoy's history of ideas: what appear to be iterations of the same idea turn out to be distinct conceptions in need of disaggregation rather than assimilation into broader narratives over time or across space. For example, liberalism in Britain was

\footnotetext{
58 Duncan Bell, 'Dissolving Distance: Technology, Space, and Empire in British Political Thought, c. 1770-1900,' Journal of Modern History 77 (2005): 523-63; Michael Lang, 'Mapping Globalization or Globalizing the Map: Heidegger and Planetary Discourse,' Genre: Forms of Discourse and Culture 36 (2006): 239-50; Benjamin Lazier, 'Earthrise; or, The Globalization of the World Picture,' American Historical Review 116 (2011): 602-30.

${ }^{59}$ Emma Rothschild, 'Arcs of Ideas: International History and Intellectual History,' in Gunilla Budde, Sebastian Conrad and Oliver Janz, eds., Transnationale Geschichte: Themen, Tendenzen und Theorien (Göttingen: Vandenhoeck \& Ruprecht, 2006), 217-26; Chris Goto-Jones, 'The Kyoto School, the Cambridge School, and the History of the Political Philosophy in Wartime Japan,' Positions: East Asia Cultures Critique 17 (2009): 13-42.
} 
not the same as liberalism in India: each developed within its own ecological niche, yet they did not emerge in ignorance of each other, but rather in dialogues mediated by local conditions of the reception, circulation, and hybridization of arguments. ${ }^{60}$ After at least the mid-eighteenth century, the conditions of reception were trans-regional and increasingly global: Indian 'liberals' in the early nineteenth century like Rammohan Roy saw their own struggles against despotism as part of worldwide movements encompassing British and Portuguese colonies in Asia, the Spanish monarchy in the Atlantic world, and Britain itself. Texts carried ideas but always amid framing paratexts, and then into unpredictable contexts for their translation and reappropriation. These conditions generated dissimilitude out of similarity, but rarely to the extent of complete disjuncture and incomparability. With such caveats in mind, the danger of falling into reification may be overblown. With methodological assistance where necessary from, say, Rezeptionsgeschichte, the history of the book, and post-colonial theory it should be possible to avoid the dangers of an older, less sophisticated, transhistorical history of ideas and replace it with a more methodologically robust transtemporal history in ideas. ${ }^{61}$

Presentism may offer a more serious danger for the international turn. 'The whole enterprise [of international intellectual history] is itself presentist, in the sense that the transnational turn is influenced, in evident respects, by the late twentieth and early twenty-first century public controversies over "globalization", 62 Yet we can no more wish away current arguments than we can deny the presence of debates over cosmopolitan, universal or global connections and conceptions in the past. It is a truism - and, like all truisms, by definition at least partly true - that our ever-changing present continually reveals aspects of the past that have been overlooked or underappreciated. In this case, as in other aspects of transnational history, two approaches are possible: 'A first would suggest that connections did exist and were known to past actors, but have for some reason been forgotten or laid aside. The task of the historian would then be to rediscover these lost traces. A second view would instead posit that

${ }^{60} \mathrm{C}$ A. Bayly, Recovering Liberties: Indian Thought in the Age of Liberalism and Empire (Cambridge: Cambridge University Press, 2011).

${ }^{61}$ David Armitage, 'What's the Big Idea? Intellectual History and the Longue Durée,' History of European Ideas 38 (2012): 000-00; Armitage, Civil War: A History in Ideas (New York: Knopf, forthcoming).

${ }^{62}$ Rothschild, 'Arcs of Ideas,' 221. 
historians might act as electricians, connecting circuits by acts of imaginative reconstitution rather than simple restitution. ${ }^{63}$ The first of these approaches-connective rather than comparative, reconstitutive rather than restitutive-might be preferable for most historians, but the second is also surely necessary for the creation of the requisite historical distance between past imperatives and current concerns. We surely delude ourselves if we imagine we do not see those concerns through a glass darkly: we will only be able to see them more clearly if we place them in long-range perspective.

'Classism' - the idea that 'only the high, or the great, or the highly educated, have been the subject, in general, of histories of the individual mind, or the individual self' - is a familiar charge against intellectual history, rather than a failing peculiar to intellectual history with an international twist. ${ }^{64} \mathrm{~J}$. S. Mill, for one, had rebutted it as early as 1838 in his defence of Bentham and Coleridge:

... speculative philosophy, which to the superficial appears a thing so remote from the business of life and the outward interests of men, is in reality the thing on earth which most influences them, and in the long run overbears every other influence save those which it must itself obey. The writers of whom we speak have never been read by the multitude; except for the more slight of their works, their readers have been few: but they have been the teachers of the teachers. ${ }^{65}$

In between the speculative philosophers and the multitude are the thinkers of what Emma Rothschild has called 'intermediate' or 'medium thoughts,' the reflections of those too undistinguished to be the subjects of individual intellectual biography but too profuse in leaving their reflective traces to be subsumed into any history of mentalités, especially, but not exclusively, those engaged in public policy of various kinds. ${ }^{66}$ Such people were

\footnotetext{
${ }^{63}$ David Armitage and Sanjay Subrahmanyam, 'The Age of Revolutions, c. 1760-1840: Global Causation, Connection, and Comparison,' in Armitage and Subrahmanyam, eds., The Age of Revolutions in Global Context, c. 1760-1840 (Basingstoke: Palgrave Macmillan, 2010), xxxi.

${ }^{64}$ Rothschild, 'Arcs of Ideas,' 222. For implied rebuttals of this accusation, see, for example, Jonathan Rose, The Intellectual Life of the British Working Classes, $2^{\text {nd }}$ edn. (New Haven: Yale University Press, 2010); Christopher Hilliard, To Exercise Our Talents: The Democratization of Writing in Britain (Cambridge, Mass.: Harvard University Press, 2007).

${ }^{65}$ J. S. Mill, 'Bentham,' London and Westminster Review 19 (August 1838): 467.

${ }^{66}$ Emma Rothschild, 'Language and Empire, c. 1800,' Historical Research 78 (2005): 210; Rothschild, 'Political Economy,' in Stedman Jones and Claeys, eds., The Cambridge History of Nineteenth-Century Political Thought, 774-76.
} 
often globetrotters and go-betweens, members of the massive Asian, European, and African migrations that crossed (and re-crossed) the Atlantic and Pacific Oceans and the steppes, but also the intercultural agents who trafficked in local knowledge and the creation of 'global intelligence'. ${ }^{67}$ As historians reconstruct their forms of intellection, and the histories of their ideas, we can expect to find even more widespread evidence of forms of transnational thinking than ever before. ${ }^{68}$

The increasingly elastic definitions of context demanded by transnational history should not deter intellectual historians. Some are beginning to ask how precisely can any idea can be understood 'in context' if context is now defined to encompass intercontinental communications, multilingual communities, or the expansion of world systems ${ }^{69}$ Here again the opportunities may be greater than the dangers. Canons of relevance must be defined, routes of active (or at least plausible) transmission mapped, and scales of reference calibrated according to contemporaries' conceptions of the international or the global; with such boundaries in place, it should be feasible to reconstruct meaningful spatial contexts for the ideas we trace across borders and bounded discursive communities.

Historicizing conceptions of space-of the national, the international, the transnational, and the global — may in fact be the implied agenda for intellectual history after the international turn, just as historicizing conceptions of time was a major project for intellectual history in the nineteenth and twentieth centuries. This agenda leads inexorably to the question what it might mean for intellectual history to take a global turn. Quite what a global intellectual history would comprise, or even what its subjectmatter will be, is still far from clear, though vigorous debate has already begun about these matters. ${ }^{70}$ Whether the global turn is just one logical extension of the international

\footnotetext{
${ }^{67}$ Simon Schaffer, Lissa Roberts, Kapil Raj, and James Delbourgo, eds., The Brokered World: Go-Betweens and Global Intelligence, 1780-1820 (Sagamore Beach: Science History Publications, 2009).

${ }^{68}$ Bose and Manjapra, eds., Cosmopolitan Thought Zones; Emma Rothschild, The Inner Life of Empires: An Eighteenth-Century History (Princeton, NJ: Princeton University Press, 2011).

69 Goto-Jones, "The Kyoto School, the Cambridge School, and the History of the Political Philosophy in Wartime Japan,' 14 ('historical context does not appear to overlap with spatiocultural context').

${ }^{70}$ Donald R. Kelley, Joseph Levine, Allan Megill, J. B. Schneewind, and Ulrich Johannes Schneider, 'Intellectual History in a Global Age,' Journal of the History of Ideas 66 (2005): 143-
} 
turn or a distinct endeavor in its own right remains to be seen. With such widening horizons and enticing prospects, it surely cannot be premature to welcome both the international and the global as turns for the better in intellectual history, as they have been for historical writing tout court.

200; Andrew Sartori, Bengal in Global Concept History: Culturalism in the Age of Capital (Chicago: University of Chicago Pres, 2008); Antony Black, 'Toward a Global History of Political Thought,' in Takashi Shōgimen and Cary J. Nederman, eds., Western Political Thought in Dialogue with Asia (Lanham, MD: Lexington Books, 2009), 25-42; Shruti Kapila, 'Global Intellectual History and the Indian Political,' in this volume; Samuel Moyn and Andrew Sartori, eds., Global Intellectual History (New York: Columbia University Press, 2013). 